\title{
Periorbital ecchymosis and shoulder pad sign in transthyretin amyloidosis
}

\author{
Ryohei Ono (ㄷ), Takatsugu Kajiyama, Hideyuki Miyauchi, Yoshio Kobayashi
}

Department of Cardiovascular Medicine, Chiba University Graduate School of Medicine, Chiba, Japan

\section{Correspondence to}

Dr Ryohei Ono;

ryohei_ono_0820@yahoo.co.jp

Accepted 21 March 2021

\section{DESCRIPTION}

A 75 -year-old man was referred for investigation of the aetiology of heart failure. He was admitted for heart failure 5 months prior, and echocardiography showed thickening of the ventricular walls and impaired diastolic function. He had also experienced shoulder stiffness bilaterally for 1 year. Physical examination revealed periorbital puffiness, ecchymosis (figure 1A) and enlarged swelling of the shoulders (shoulder pad sign, figure 1B).

Periorbital ecchymosis and the shoulder pad sign are classically considered pathognomonic of acquired monoclonal immunoglobulin light-chain (AL) amyloidosis. The blood and urinary immunoelectrophoresis and a nephelometric assay of the light chain in serum were examined, but they were negative. Thus, a myocardial biopsy was performed. Amyloid deposits were detected based on positive results of immunofluorescence using transthyretin (TTR) antibodies (figure 2A-D). Molecular analysis of the TTR gene was performed, but it revealed no mutations, resulting in a diagnosis of wild-type TTR amyloidosis. The patient has been under consideration for taking tafamidis, an oral TTR tetramer

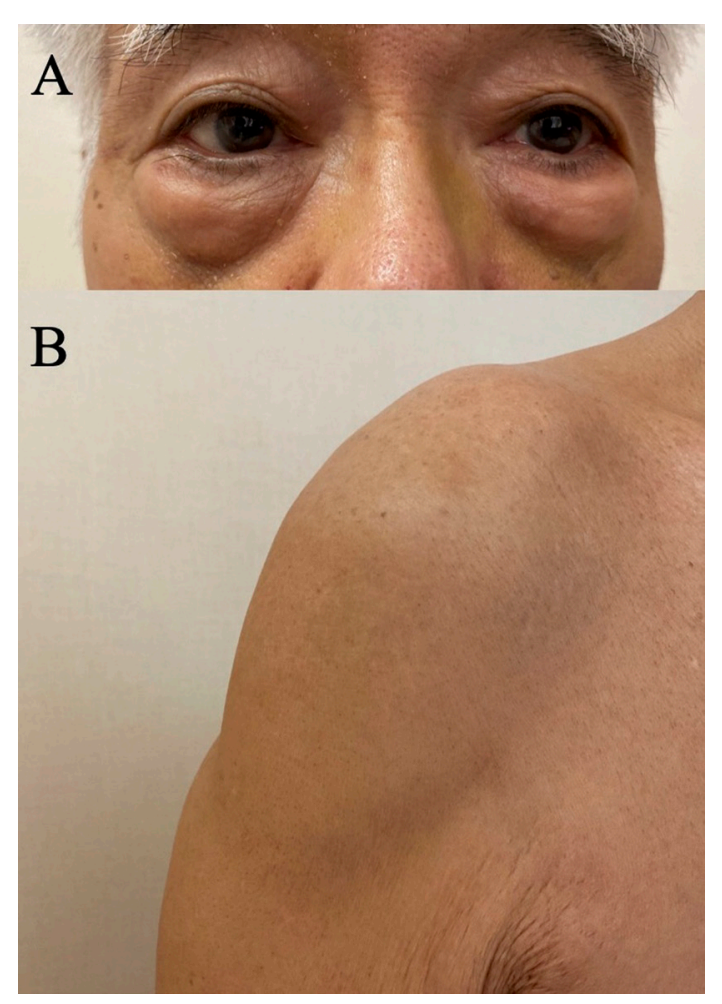

Figure 1 (A) Physical examination showing periorbital puffiness and ecchymosis. (B) Enlarged swelling of the shoulders indicating the shoulder pad sign.

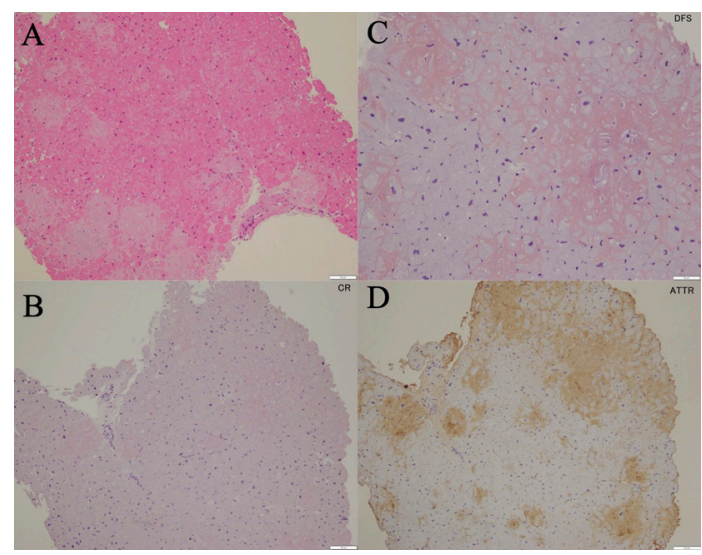

Figure 2 (A) HE stain. (B) Congo red-stained biopsy of myocardium showing amyloid deposits. (C) Direct fast scarlet stain revealing amyloid deposits. (D) Positive staining for antitransthyretin antiserum on immunohistochemistry.

stabiliser, which binds to TTR and prevents tetramer dissociation and amyloidogenesis.

Periorbital ecchymosis, also known as raccoon eyes, is observed in amyloidosis. Amyloid deposition leads to vascular fragility and bleeding diathesis is caused by vessel wall damage. ${ }^{1}$ In addition, the shoulder pad sign is a typical feature of amyloidosis, which results from amyloid deposition in the periarticular soft tissue of the shoulders. Periarticular swelling is associated with pain, stiffness and decreased range of motion. ${ }^{2}$

Periorbital ecchymosis and the shoulder pad sign are rarely reported in TTR amyloidosis compared with that in AL amyloidosis. ${ }^{3}$ However, regardless of the type of amyloidosis, these signs are considered manifestations that may offer diagnostic clues of amyloidosis.

\section{Learning points}

- Periorbital ecchymosis and the shoulder pad sign are typical physical features of amyloidosis.

- Periorbital ecchymosis and the shoulder pad sign are observed in not only immunoglobulin light-chain amyloidosis but also transthyretin amyloidosis.

Contributors $\mathrm{RO}, \mathrm{TK}$ and $\mathrm{HM}$ contributed to the patient care and wrote the manuscript. YK contributed to critical revision of the article and approved the final version.

Funding The authors have not declared a specific grant for this research from any funding agency in the public, commercial or not-for-profit sectors. 


\section{Images in...}

Competing interests None declared.

Patient consent for publication Obtained.

Provenance and peer review Not commissioned; externally peer reviewed.

ORCID iD

Ryohei Ono http://orcid.org/0000-0002-4875-7470

\section{REFERENCES}

1 Colucci G, Alberio L, Demarmels Biasiutti F, et al. Bilateral periorbital ecchymoses. An often missed sign of amyloid purpura. Hamostaseologie 2014;34:249-52.

2 Guerreiro de Moura CG, Pinto de Souza S. Images in clinical medicine. "Shoulder pad" sign. N Engl J Med 2004;351:e23.

3 Outteryck O, Stojkovic T, Launay D, et al. Periorbital ecchymoses are not pathognomonic of the light-chain type of amyloidosis. Acta Derm Venereol 2007;87:544-5.

Copyright 2021 BMJ Publishing Group. All rights reserved. For permission to reuse any of this content visit

https://www.bmj.com/company/products-services/rights-and-licensing/permissions/

BMJ Case Report Fellows may re-use this article for personal use and teaching without any further permission.

Become a Fellow of BMJ Case Reports today and you can:

- Submit as many cases as you like

- Enjoy fast sympathetic peer review and rapid publication of accepted articles

- Access all the published articles

Re-use any of the published material for personal use and teaching without further permission

Customer Service

If you have any further queries about your subscription, please contact our customer services team on +44 (0) 2071111105 or via email at support@bmj.com.

Visit casereports.bmj.com for more articles like this and to become a Fellow 